\title{
日立鉱業所における鍰選鉱の現況について
}

\author{
寉开 \\ 長山定雄**
}

\section{Flotation of Copper Converter Slag at Hitachi Mine}

Yutaka KUBOTA and Sadao NAGAYAMA

\section{I はじめに}

従来、各製鍊所で採用している銅鉱乾式製鍊法は、銅

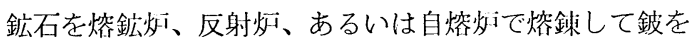
つくり、これを転炡に装入して粗銅に仕上げるものであ

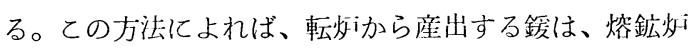
あるいは反射炕に絽返して処理されるのが畨通である。 この繰返し処理のために燃料、熔剂の使用量がかさみ、 また、熔鍊能率にも影響をおよぼすほか、鍰逃げの金、 銀、銅を増し、さらには、鍰中の鉄分を積極的に回収す ることができないという不利がある。

当所においては、転灿に銅鉱石の大部分を直装入し、 酸素富化空気の使用によつて一挙に粗銅にまで仕上げて いわゆる、「転炕による銅鉱の酸素製鍊法」を採用して いる。産出する転炉鍰の量が、他の製鍊法にくらべて、 激増することは明らかであり、それを熔鉱灿に繰返した のでは酸素製鍊の意味がなくなる。この転炏瑗の脱銅を いかにして解決するかは、酸素製鍊法の重姴なポイント の一つであつた。酸素製鍊法により座出される転必韨の 性質は從来の転炏撹業におけるものと、ほとんど问じで あつて、普通の $\mathrm{Cu} 4$ 〜 \%、Fe45〜50\%、楥中の銅の 大部分は白鈹に近い状態であり、鉄は硅酸塭之酸化鉄と である。この脱銅方法については、はじめ、熔体のまま で脱銅を行うことも考えてみたのであるが、種々の困難 があるので選鉱処理による脱銅に主力を注ぎ、遊休設借 を利用した $1,000 \mathrm{~T} /$ 月の規模の現場試験を行い、満足 すべき結果が得られた。酸素製鍊法採用の決定により $4,500 \mathrm{~T} /$ 月処理の鍰選鉱場を建設し、炤和 32 年 7 月末よ り実操業を行つている。

\section{II 操 業の 概 要}

(1) 位置および建家

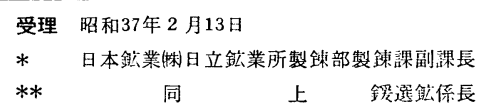

日立鉱業所製鍊所構内の旧粉砕炭工埸の建家および熔 鉣炉鉱含の建家の一部を利用して建設し、総建坪は約 390 坪である。

(2) 粉砕およで磁選

粗砕は $30^{\prime \prime} \times 18^{\prime \prime}$ ブレーキクラッシャ、細砕はセカン ダリーギャレスクラッシャ（ＳR25）を $4^{\prime} \times 8^{\prime}$ ローへ ッドスクリーン $(15 \mathrm{~mm}$ 目) と閉回路に使用する系統で 行い、-15mm としててれを磁選機（S L-66B型）に より磁性物および非磁性物に分離し、磁性物はミル鉱舎 へ送り、非磁性物は白鈹の高品位部分であるので銅製鍊 繰返しとしている。

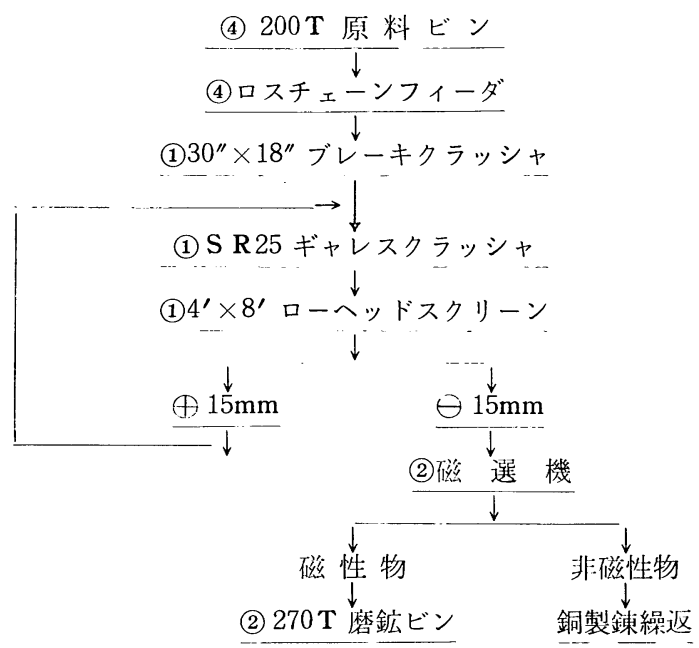

\section{第1図 粉 砕、磁選 系 統}

（3）磨 鉱 浮 選

浮選尾鉱の含銅を低下させるためには微粉砕の必要が ある。また、最初からこれまで微粉砕するときは銅精鉣 品位が低下するので、商品位の精鉱を得るには粗粒でな けれればならない。この相反する性質のためにユニットセ ル㴊用による多段磿鈗系統を採用し、ミル効率の上昇と 


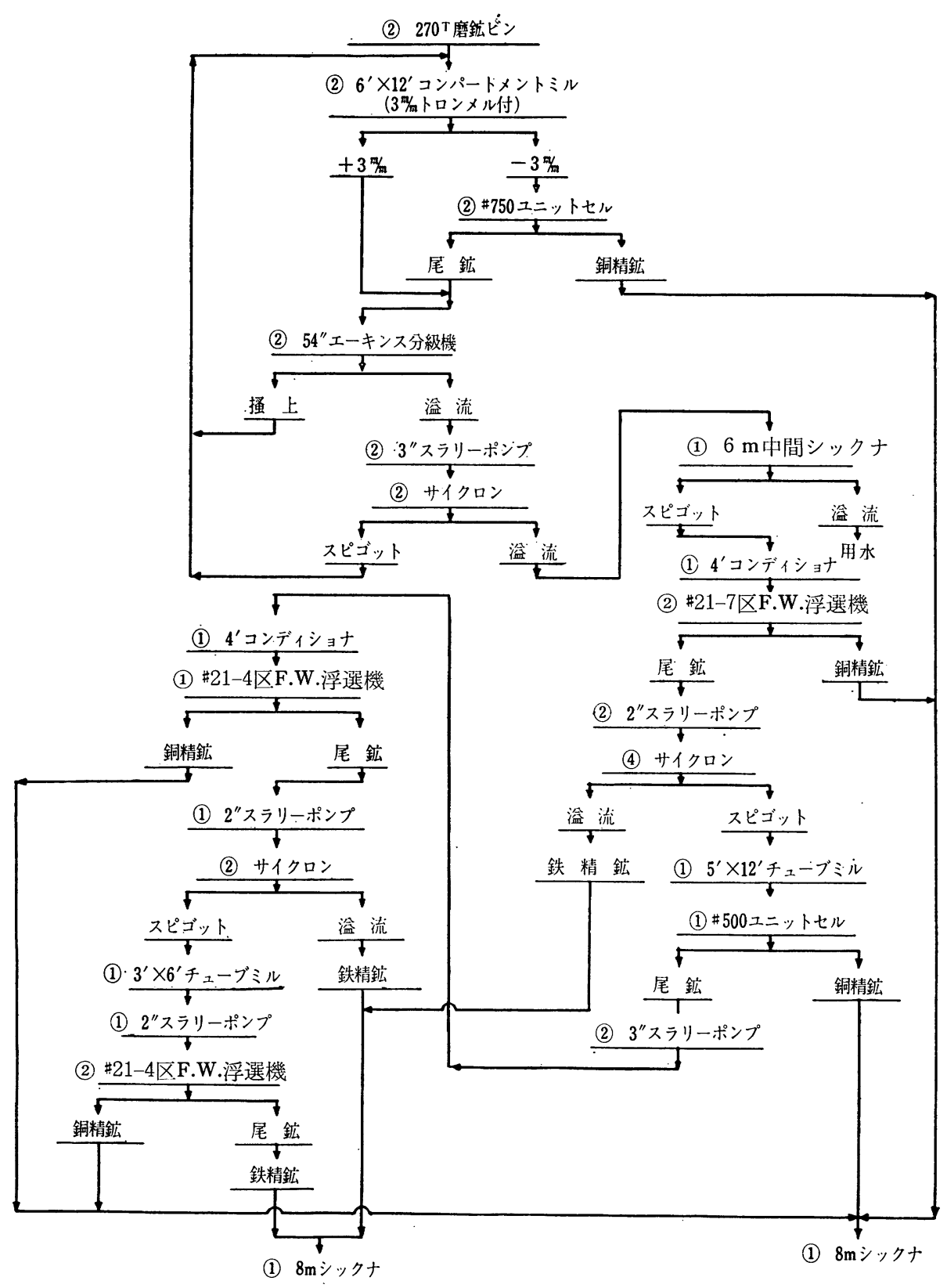

第 2 図磨鉱浮選系統

銅精鉱品位の向上とを図つている。すなわち、一次磨鉱 機としては $6^{\prime} \times 12^{\prime}$ コンパートメントミルを使用し、磨 鉱回路にユニットセルを設置する。そして、一次浮選尾 鉱中の粗粒部を $5^{\prime} \times 12^{\prime}$ チューブミルにより二次監鉱し た上二次浮選にかけ、さらに、二次浮選尾鈗の粗粒部に
対して三次磨鉱および浮選を行うのである。

（4）銅精鉱、鉄精鉱とあ、シックナーで洪縮したの ち、オリバーフィルタで脱水する。銅精鈗は銅製鋉繰这 し、鉄精鉱は製鉄原料として売り出す。 

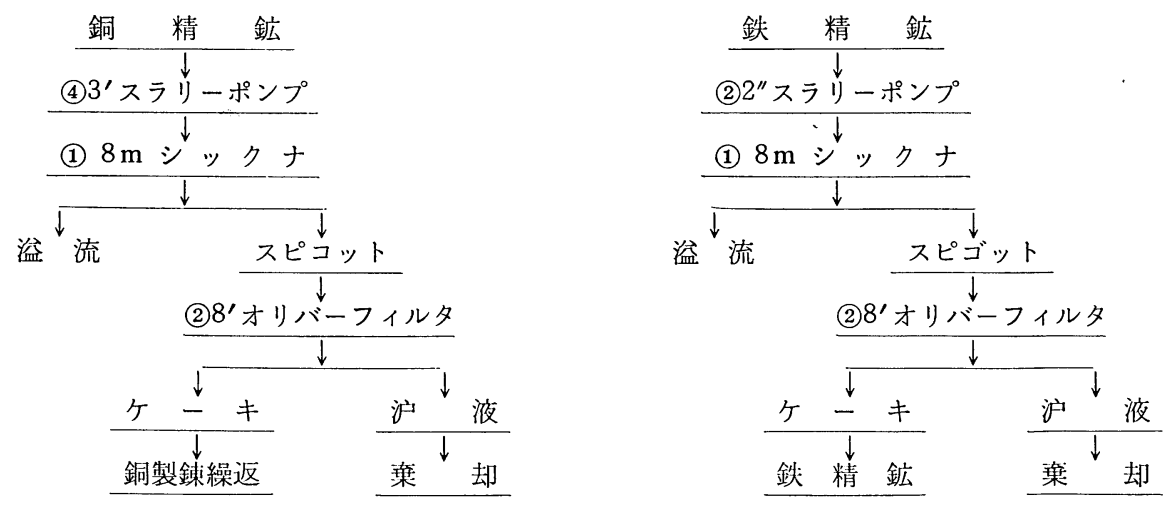

第 3 図精鉱 処理系統

（5）稼働人員

姴務 職 4 名（係長 1 名、担任 3 名）

夹鉱務職 30名

\begin{tabular}{|c|c|c|}
\hline 粉砕、磁選 & 3 (2 交代) & ) 6 \\
\hline 磨鉱、浮選 & 3 (3 交代) & ) 9 \\
\hline 精鉱処理 & 1 (3交代) & ) \\
\hline 機械修理 & & \\
\hline 測 & & \\
\hline 補 助 員 & & \\
\hline 勤(女子) & & \\
\hline 計 & & 30 \\
\hline
\end{tabular}

\section{III 操 業 成 結}

(1) 粉 砕

i ）ブレーキクラッシャ $30^{\prime \prime} \times 18^{\prime \prime}$

給鉱サイズ 最大

$300 \mathrm{~mm} \times 300 \mathrm{~mm} \times$

排出物の大きさ

$200 \mathrm{~mm}$

ライナ消耗量

$\begin{array}{cl}\text { 受歯板 } & 2.2 \mathrm{~g} / \mathrm{T} \\ \text { 動歯板 } & 2.9 \mathrm{~g} / \mathrm{T} \\ \text { 計 } & 5.1 \mathrm{~g} / \mathrm{T}\end{array}$

ii ) ギャレスクラッシャ

給鉱サイズ 最大 $\quad 100 \mathrm{~mm}$

排出物の大きさ $12 \mathrm{~mm}$

ライナ消耗量

$$
\begin{array}{ll}
\text { クラッシングリング } & 6.5 \mathrm{~g} / \mathrm{T} \\
\text { マントル } & 5.6 \mathrm{~g} / \mathrm{T}
\end{array}
$$

ローヘッドスクリーンを閉回路として使用してお

り、循環率は約43.5\%である。

iii）磁選機（三菱 S L-66B型）直流 $440 \mathrm{~V}$

給鉱サイズ

$-15 \mathrm{~mm}$

処理鉱量
(2) 磨鉱、浮選

i ）細度および濃度

$-325 \times ッ シ ュ$

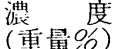

ミル給鉱 $(+3 \mathrm{~mm} \mathrm{76.5 \% )}$

一次浮選原鉱 $86.0 \quad 40.0$

二次浮選原鉱 $88.0 \quad 36.0$

三次浮選原鉣 $90.0 \quad 36.0$

銅 精 鉱 77.511 .0 (水分)

鉄 精 鉱 92.511 .5 (水分)

ii）浮 選 剂

$\left.\begin{array}{l}\text { 高砂油 \# } 10 \\ \text { 日香油 \# 10-B }\end{array}\right\}$ 混合油 $(5: 5)$

Na-E.X （10\%溶液として使用）

浮選剂の添加場所および使用量は次のとおりであ る。

\begin{tabular}{|c|c|c|}
\hline 添加場所 …… 種 類 & $\begin{array}{l}\text { 泚合 油 } \\
(\mathrm{g} / \mathrm{T})\end{array}$ & $\begin{array}{l}\text { Na-E.X } \\
(\mathrm{g} / \mathrm{T})\end{array}$ \\
\hline \multicolumn{3}{|l|}{$6^{\prime} \times 12^{\prime}$ コンパートメントミル } \\
\hline " 出口 & 69.0 & 269 \\
\hline 一次コンデイショナ & 11.0 & 56 \\
\hline \multicolumn{3}{|l|}{$5^{\prime} \times 12^{\prime}$ チューブミル } \\
\hline " 出口 & 16.5 & 42 \\
\hline 二次コンディショナ & 15.0 & 45 \\
\hline 三 次 浮 選 機 & 10.0 & 31 \\
\hline & 121.5 & 443 \\
\hline
\end{tabular}

第 1 表 浮選剂 の 使用例

iii）ボール使用量(使用量は一次磨鉱取扱鉱量当り) $6^{\prime} \times 12^{\prime}$ コンパートメントミル 給鉱側は 4 “、排出側は $21 / 2 "$ のボールを使用し、 使用量は次のとおりである。

給鉱側 $481 \mathrm{~g} / \mathrm{T}$ 


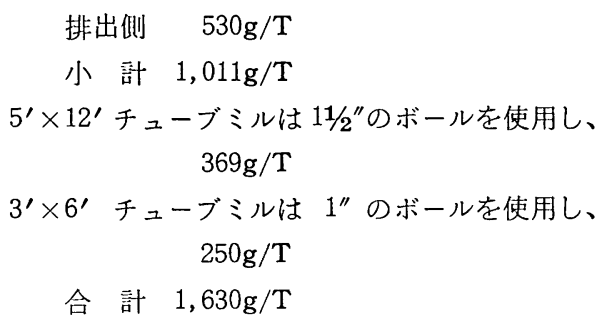

（3）鉱量成績

第 2 表 浮選鉱量成績の 1 例

\begin{tabular}{|c|c|c|c|c|c|}
\hline \multirow{2}{*}{ 鉱 } & \multirow{2}{*}{$\begin{array}{r}\text { 鉱 量 } \\
\mathrm{T}\end{array}$} & \multicolumn{2}{|c|}{ 品 } & \multicolumn{2}{|c|}{ 位 } \\
\hline & & $\mathrm{Cu} \%$ & $\mathrm{Fe} \%$ & $\begin{array}{r}\mathrm{Au} \\
\mathrm{g} / \mathrm{T}\end{array}$ & $\underset{\mathrm{g} / \mathrm{T}}{\mathrm{Ag}}$ \\
\hline 選 鉱原 鍰 & 4,395 & 6.70 & 45.60 & 2.1 & 51 \\
\hline 磁選精 鉱 & 308 & 35.91 & 26.00 & 11.0 & 260 \\
\hline 浮選原鍰 & 4,087 & 4.50 & 47.08 & 1.4 & 35 \\
\hline 銅 精 鉱 & 1,099 & 15.70 & 40.00 & 5.0 & 124 \\
\hline 鉄 精 鉱 & 2,900 & 0.38 & 49.69 & 0.1 & 2 \\
\hline 溢流廃㨀 & 88 & 0.38 & 49.69 & 0.1 & 2 \\
\hline
\end{tabular}

\section{IV 現操業におけるニ、三の考察}

(1) 磁選

転炉鍰品位はかなりのバラツキがあり、粉砕後直ちに
磨鉱 $\rightarrow$ 浮選を行う場合は、浮選操業に相当な混乱を招く ことは想像に難くない。この点、浮選給鉱品位の均一化 のクッションをなしているのである。

磁選精鎕 (非磁性物) 中の $\mathrm{Fe}$ 品位は26〜28\%であり、 磁選尾鉱（磁性物、ミル給鉱）は47〜49\%であり、この $\mathrm{Fe}$ 品位の差が磁選を可能にしているので、磁束密度、 サーチコイルとドラムとの間隔、分離仕切板等を適正に 調節するととにより好成績が得られる。従つて、磨鉱鉱 量の減少に大いに役立つていることはいうまであなく、 仮に受入処理鉱の増大を望む場合は、精鉱品位を許容線 まで低下させて精鉱量を増加させることも可能である。

以上のとおり、鍰選鉱工程における磁選の役割は誠に 大きく、爾後の操羍を円滑ならしめている。

(2) 磨 鉱

転炉鍰の浮選については、浮選の操作もさるととなが ら、最む重大なポイントをなすすのは浮選給鉱のサイズ であり、磨鉱操業の成否のいかんである。磨鉱において 含銅鍰粒于の単体分離に成功しさえすれば、その後の浮 選は割合容易である。転炉鍰が鉱石と異るととは明らか であつて、これの特性を熟知して磨鉱方法その他を決定 するてとが最あ好ましいことである。当所においても種 々試験を实施したが、第 3 表は含銅硫化鉱と転炉鍰の磨 鉱比較の一例で、これについてみると、次のようなこと がいえる。

第 3 表＼cjkstart含銅硫化鉱および転炉鍰の給鉱サイズ別磨鉱表

\begin{tabular}{|c|c|c|c|c|c|c|c|c|c|c|c|c|}
\hline 給 & 鉱 & & & & 鉱 & 生 & 成 & の & 節 & $(\%)$ & & \\
\hline 節 目 & $\begin{array}{l}\text { 平 均 } \\
\text { サイズ }\end{array}$ & & $6 \sim 3 \mathrm{~mm}$ & $3 \sim 1$ & $\begin{array}{c}\text { メッシュ } \\
1 \sim 48\end{array}$ & $48 \sim 100$ & $\mid 100 \sim 200$ & $200 \sim 300$ & $300 \sim 400$ & -400 & 計 & -300 \\
\hline $16 \sim 9$ & 12. ${ }_{6}^{\mathrm{mm}}$ & $\begin{array}{l}\text { 硫化 } \\
\text { 鍰 }\end{array}$ & $\begin{array}{l}27.1 \\
91.24\end{array}$ & $\begin{array}{l}0.40 \\
0.34\end{array}$ & $\begin{array}{l}0.20 \\
0.05\end{array}$ & $\begin{array}{l}1.45 \\
0.15\end{array}$ & $\begin{array}{l}7.10 \\
0.37\end{array}$ & $\begin{array}{l}9.35 \\
0.62\end{array}$ & $\begin{array}{l}6.60 \\
0.39\end{array}$ & $\begin{array}{r}47.80 \\
6.84\end{array}$ & $\begin{array}{l}100 \\
100\end{array}$ & $\begin{array}{l}54.4 \\
7.25\end{array}$ \\
\hline $9 \sim 6$ & 7. 9 & $\begin{array}{l}\text { 硫化 } \\
\text { 鍰 }\end{array}$ & & & $\begin{array}{l}0.3 \\
0.15\end{array}$ & & $\begin{array}{l}8.95 \\
2.62\end{array}$ & $\begin{array}{l}13.3 \\
4.51\end{array}$ & $\begin{array}{l}5.65 \\
2.28\end{array}$ & $\begin{array}{l}51.85 \\
23.44\end{array}$ & $\begin{array}{l}100 \\
100\end{array}$ & $\begin{array}{l}57.5 \\
25.73\end{array}$ \\
\hline $6 \sim 3$ & 4. 7 & $\begin{array}{l}\text { 硫化 } \\
\text { 鍰 }\end{array}$ & $\begin{array}{r}1.90 \\
21.77\end{array}$ & & $\begin{array}{l}0.20 \\
0.15\end{array}$ & & $\begin{array}{l}10.90 \\
11.04\end{array}$ & $\begin{array}{r}22.70 \\
4.32\end{array}$ & $\begin{array}{l}5.20 \\
4.28\end{array}$ & $\begin{array}{l}56.90 \\
54.35\end{array}$ & $\begin{array}{l}100 \\
100\end{array}$ & $\begin{array}{l}62.10 \\
58.64\end{array}$ \\
\hline $3 \sim 1$ & 2. 05 & $\begin{array}{l}\text { 硫化 } \\
\text { 鍰 }\end{array}$ & & 0.80 & $\begin{array}{l}0.10 \\
0.40\end{array}$ & $\begin{array}{l}1.00 \\
0.80\end{array}$ & $\begin{array}{r}10.60 \\
4.80\end{array}$ & & $\begin{array}{r}9.20 \\
11.90\end{array}$ & $\begin{array}{l}60.30 \\
65.20\end{array}$ & $\begin{array}{l}100 \\
100\end{array}$ & $\begin{array}{l}69.50 \\
77.10\end{array}$ \\
\hline $\begin{array}{c}\text { メッシ } \\
1 \sim 48\end{array}$ & 0.67 & $\begin{array}{l}\text { 硫化 } \\
\text { 鍰 }\end{array}$ & & & $\begin{array}{l}0.10 \\
0.20\end{array}$ & $\begin{array}{l}1.80 \\
0.80\end{array}$ & $\begin{array}{l}6.50 \\
4.90\end{array}$ & $\begin{array}{l}17.6 \\
11.50\end{array}$ & $\begin{array}{l}10.70 \\
14.30\end{array}$ & $\begin{array}{l}63.30 \\
68.30\end{array}$ & $\begin{array}{l}100 \\
100\end{array}$ & $\begin{array}{l}74.00 \\
82.60\end{array}$ \\
\hline $48 \sim 100$ & 0.22 & $\begin{array}{l}\text { 硫化 } \\
\text { 鏑 }\end{array}$ & & & & 1.40 & 4.50 & 14.90 & 12.70 & 66.50 & 100 & 79.2 \\
\hline $100 \sim 200$ & 0.11 & $\begin{array}{l}\text { 硫化 } \\
\text { 鍰 }\end{array}$ & & & & & 3.10 & 13.70 & 11.40 & 71.80 & 100 & 83.20 \\
\hline $200 \sim 300$ & 0.063 & $\begin{array}{l}\text { 硫化 } \\
\text { 鍰 }\end{array}$ & & & & & & 10.90 & 15.90 & 73.20 & 100 & 89.10 \\
\hline $300 \sim 400$ & 0.045 & $\begin{array}{l}\text { 硫化 } \\
\text { 鍰 }\end{array}$ & & & & & & & 31.20 & 68.80 & 100 & 100 \\
\hline
\end{tabular}

注）試料は48メッシュ以上のあのについては中砕したあのを各サイズ別に調整し、それ以下のものは磨鉱生 成物を節別して 48〜100、100〜200 メッシュ等のむのに調整した。 
給鉱サイズ $5 \mathrm{~mm}$ までは含銅硫化鉱が微粉を多く生成 し、それ以下のサイズでは転炉鍰が磨鉱し易く、微粉を 生じ易い。また、給鉱サイズを順次に小さくしていく と、 $1 \mathrm{~mm}$ 以下の場合微粉の生成量は渐次少なくなる。 100、200メッシュ程度になると、ほとんど生成量は一定 で、変化がないようになる。すなわち、細砕になる程稜 角を失い、球形に近ずき、組織むまた緻密で軼裂等が少 なくなるため、磨鉱は著しく困難になる。当所の転炉鍰 中の含銅粒于は非常に維密に赋存しているので、現在は 最終浮選給鉱サイズをー325メッシュ90\%程度で操業し
ているが、との程度では不十分であり、さらに磨鉱効率 の向上が望まれる。しかし、使用中のミル（一次コンパ ートメントミル、二、三次チューブミル）では、一次ミ ルはともかく、二、三次ミルでは（上記鍰の特性から判 断して)、てれ以上の磨鋐効率の向上は 望み薄であり、 换言すれば、チューブミルの可否が疑問視される。

(3) 浮 選

浮選操業において、最も重要なポイントは上記のとお り給鉱サイズのいかんであり、第 4 表の浮選試験結果か らも容易に首肯される。

\section{第い表 浮選に対する鉱粒サイズの影響}

\begin{tabular}{|c|c|c|c|c|c|c|c|}
\hline \multirow{2}{*}{ 鉱 種 サイズ } & 銅 & \multicolumn{2}{|c|}{ 位 （\%) } & \multirow{2}{*}{$\begin{array}{r}\text { 精 鉱 率 } \\
96\end{array}$} & \multirow{2}{*}{$\begin{array}{r}\text { 銅採収率 } \\
\%\end{array}$} & \multicolumn{2}{|c|}{ 銅 品 位 $の$ 比 } \\
\hline & フイード & ᄀㅈ & テ $-ル$ & & & フロスノ゙ィート & テール/フィート \\
\hline 原 & 3.51 & 7.00 & 0.60 & 45.5 & 90.7 & 1.99 & 0.17 \\
\hline 100〜200メッシュ & 2.65 & 5.29 & 0.68 & 55.5 & 88.6 & 2.00 & 0.19 \\
\hline $200 \sim 300$ & 4.42 & 8.24 & 0.61 & 50.0 & 93.2 & 1.86 & 0.14 \\
\hline-300 粗 粒 & 4.05 & 7.51 & 0.48 & 50.8 & 94.2 & 1.85 & 0.12 \\
\hline-300 微 粉 & 3.41 & 8.24 & 0.32 & 39.2 & 94.3 & 2.42 & 0.09 \\
\hline
\end{tabular}

注）浮選条件は同一とし、供試試料は分級機溢流鉱を 篩別して各サイズ別に試料を調整。乙れにつき、そ れぞれ、浮選試験を行つた。なお -300 メッシュ以 下の分は比較的粗粒の部分之微粉の部分之に二分し た。

すなわち、

(i) 給鉱サイズが100〜200メッシュより -300 メ ッシュ微粉にいた机ば、尾鉱品位む $0.68 \%$ より $0.32 \%$ 之顕花に低下寸る。

（ii）乙机を給鉱銅品位に対する品位の比で表わす と、0.19より0.09というように、給鉱の微細化 に伴つて著しい低下を示す。

(iii）同じく、給鉱サイズとフロス品位の関係をみ ると、5.29\%より $8.24 \%$ とい上列を示してい る。

（iv）フロス品位と給鉱品位の比をと机ば、最岀は -300メッシュ微粉が 2.42 を示し、100〜200メ ッシュの粗粒の部分がこれについでいる。

これは、白鈹等の磨鉱し難い、浮遊し易い粗 粒部分がこれに含まれているためと思われる。 （v）サイズの微細化に伴つて精鉱率は低下し、銅 採収率む上型する。

（vi） 100〜200メッシュの部分の給鉱品位の低いて とは、磨鉱より逃れ易い軽質の有機質ないしは 炭質物を含むためかと思わ机る。

以上のとおり給鉱サイズのいかんに左右されるわけで あり、その他の条件については、濃度の最適は約 $40 \%$ （重量比）前後、 $\mathrm{pH}$ は 6.8 7.0、また、試薬について は、起泡剂は比較的起泡力鬥盛なむのがよく、捕収剂は 現在、Na-E. Xanthate を単独で使用しているが、現在 までの経験では他の捕収剂を使用しても大きな差異は認 めら机ない。

\section{V おわりに}

以上、主な事項について概袈を述べたが、鍰選鉱が発 足して以来まだ日が浅く、さらに改善を泪する種々な点 が山積している。要は酸素製鍊法の効果をさらに大なら しめるため原単位の引下げ、精鉱品位の上系、精鉱率の 低下ならびに 銅採収率の上昇に一段の努力が装望され る。 